\title{
Physical activity during the school day in public primary schools in Mexico City
}

\author{
Nancy Jennings-Aburto, $\mathrm{PhD}$, (I) Fernanda Nava, MS, (I) Anabelle Bonvecchio, MPH, ${ }^{(1)}$ \\ Margarita Safdie, MS, (I) Inés González-Casanova, BS, (I) Tiffany Gust, MPH, (I) Juan Rivera, PhD.(I)
}

\section{Jennings-Aburto N, Nava F, Bonvecchio A, Safdie M, González-Casanova I, Gust T, Rivera J. Physical activity during the school day in public primary schools in Mexico City. Salud Publica Mex 2009;5I:141-147.}

\begin{abstract}
Objective. To quantify the physical activity (PA) of students and describe the school environment surrounding PA. Material and Methods. Between November 2005 and March 2006, in Mexico City, we conducted quantitative and qualitative observations to describe the PA and the school context. Results. Recess and physical education class (PE) were the only opportunities to participate in PA.PE occurred one time per week with a duration of $39.8 \pm 10.6$ minutes which is less than national and international recommendations. Students participated in moderate-to-vigorous PA $29.2 \pm 17.8 \%$ of PE. The dynamics of PE did not promote the inclusion of all students or PA. During recess there was overcrowding of the school patio and no equipment for PA or organization of PA. Discussion. The PA of students in public schools in Mexico City can be improved by increasing the quantity and quality of $\mathrm{PE}$ and increasing opportunities for activity during recess.
\end{abstract}

Key words: physical activity; child; Mexico; obesity
Jennings-Aburto N, Nava F, Bonvecchio A, Safdie M, González-Casanova I, Gust T, Rivera J.

La actividad física durante la jornada escolar en escuelas primarias públicas en la Ciudad de México Salud Publica Mex 2009;51:141-147.

\section{Resumen}

Objetivo. Cuantificar la actividad física (AF) en niños escolares y describir el entorno escolar relacionado con la AF. Material y métodos. Entre noviembre de 2005 y marzo de 2006 en la Ciudad de México, se realizó observación directa cuantitativa y cualitativa para describir el nivel de AF y el contexto escolar durante recreo y clases de educación física (CEF). Resultados. El recreo y las CEF fueron los únicos espacios en los que se realizó AF. Las CEF se impartieron una vez a la semana y duraron $39.8 \pm 10.6$ minutos, lo que está por debajo de las recomendaciones internacionales. Se participó en actividades moderadas-vigorosas $29.2 \pm 17.8 \%$ de las CEF. La dinámica de las CEF no favoreció la AF. Durante el recreo se observó saturación del patio y no se realizaron actividades organizadas ni se utilizaron materiales para promover la AF. Discusión. Se recomienda incrementar la calidad y la cantidad de las CEF y el tiempo dedicado a jugar durante el recreo.

Palabras claves: actividad física; escolares; México; obesidad
$\mathrm{T}$ The 2006 National Health and Nutrition Survey of Mexico revealed that nearly $26 \%$ of Mexican schoolaged children ( 5 to 11 years) have an unhealthy weight, ${ }^{1}$ defined as either overweight or obesity according to BMI cut-points established by the International Obesity Task
Force. ${ }^{2}$ Perhaps more alarming than the high prevalence of unhealthy weight was the sharp rise, almost $33 \%$, in only seven years in this age group. ${ }^{1,3}$

Though the etiology of obesity is complex, the root cause is an imbalance between energy intake and

(I) Instituto Nacional de Salud Pública, Centro de Investigación en Nutrición y Salud. Cuernavaca, México. 
expenditure. ${ }^{4}$ Because physical activity is the only component of energy expenditure that can be altered voluntarily, the study of physical activity is a crucial component of research in the field of unhealthy weight. Additionally, there are numerous benefits to physical activity in childhood including improved motor development, balance and flexibility, ${ }^{5}$ increased bone strength, ${ }^{6}$ improved insulin sensitivity, ${ }^{7}$ increased self-esteem, reduced depression, ${ }^{8}$ and the formation of lifelong exercise habits. ${ }^{9}$

The physical and social environments of the school can influence the physical activity of students. ${ }^{10}$ The school physical education class (PE) is important for training active behaviors and instilling the importance of an active lifestyle. ${ }^{11-13}$ A number of school-based interventions have successfully increased physical activity both in and out of school, ${ }^{13}$ improved physical fitness ${ }^{14}$ and reduced unhealthy weight. ${ }^{15-17}$ Kain and colleagues published the only account of a school-based intervention in Latin America. ${ }^{17}$ The report highlighted the differences in school environments between the United States and Latin American countries which impact intervention effectiveness. ${ }^{15}$ Successful interventions to combat the problem of unhealthy weight in Mexican children are urgently needed; however, currently there is no information regarding the physical activity of Mexican children nor is there information regarding the school environment in terms of the physical activity of students. The first step in designing and implementing a successful intervention is the diagnosis of the problem(s) and its environmental context. ${ }^{18}$ The objective of this investigation was to evaluate the physical activity of students attending public schools in Mexico City and describe the school environment regarding the practice of physical activity during the school day.

\section{Material and Methods}

Sample: This investigation was a component of a large intervention trial to combat unhealthy weight in Mexican children conducted by the National Institute of Public Health, Mexico (INSP, per its abbreviation in Spanish); it was conducted in Mexico City from November 2005 to March 2006. The sample size was based on the theory of information saturation commonly used in qualitative research. The literature supports the use of generalization of results based on this theory when the sample selected is typical of the general population. ${ }^{19}$ In order to select a typical sample, the Secretary of Education (SEP, per its abbreviation in Spanish) provided a list of schools which most closely reflected the majority of schools in Mexico City (morning-session schools, classified by the SEP as low socioeconomic status, beneficiary of the Federal
School Breakfast Program). For logistical reasons the study was confined to the southern area of Mexico City and, for the implementation of the study, the schools were required to possess minimum facilities necessary for study execution as well as the set of sports equipment issued by SEP, and have a population of at least $300 \mathrm{stu}-$ dents and at least two classrooms per grade. There were a total of 1286 morning-session schools in Mexico City. In the southern area of the city there were four delegations with a total of 274 schools, of which, 83 met all inclusion criteria. We randomly chose 12 schools from those 83 .

We used a two-step process to select students for the physical activity measurement in the current study. Because the intervention of the larger study included $4^{\text {th }}$ and $5^{\text {th }}$ grade students, first, we randomly selected one $4^{\text {th }}$ or $5^{\text {th }}$ grade classroom from each school. Second, we randomly selected $33 \%$ of the students from each classroom using a computer-generated random-number list.

Project staff visited each school and held informational meetings with the parents of all eligible students. Parents who were willing to have their child participate signed an informed consent. The Research, Ethics and Biosecurity Commissions of the INSP reviewed and approved the study protocol.

Quantitative observation: We used the SOFIT (System for Observing Fitness Instruction Time) direct observation instrument to quantify students' activity level and describe the lesson context during recess and PE. This method has been described elsewhere. ${ }^{20,21}$ In summary, observers recorded intensity of physical activity and class context using a time-sampling system of 10-second intervals. ${ }^{21}$ Observers coded intensity of physical activity as: 1- lying, 2- sitting, 3- standing, 4walking and 5-very active (requiring more energy than ordinary walking). Observers coded lesson context as: general content, general knowledge, physical activity knowledge, fitness, skill practice, game play, and free play (table I). Studies have reported the validity and reliability of SOFIT to quantify the proportion of time students are engaged in moderate to vigorous physical activity (MVPA). ${ }^{22,23}$

Field procedures: Trained observers achieved a concordance of at least $90 \%$ with the expert before beginning data collection. Re-standardization occurred periodically throughout data collection.

Before PE began, the observers placed themselves where they could listen to the professors' instructions and see the entire class. During recess, the observers moved around the school patio in order to observe all behavior. Observation began the moment the students entered the school patio and continued until students returned to their classrooms. Observation did not interfere with students' activities. 


\section{Table I}

\section{DefinItION AND EXAMPLES OF SEVEN CATEGORIES OF CLASS} CONTEXT CODED WITH SOFIT DIRECT OBSERVATION*

\begin{tabular}{lll} 
Coding category & \multicolumn{1}{c}{ Definition } & \multicolumn{1}{c}{ Examples } \\
General content & Administration of class & Taking role, transitions, rest \\
\hline $\begin{array}{l}\text { General } \\
\text { knowledge }\end{array}$ & $\begin{array}{l}\text { Lesson in physical education } \\
\text { that is not related to health } \\
\text { benefits of activity }\end{array}$ & $\begin{array}{l}\text { Explanation of rules, tech- } \\
\text { niques, strategies of class } \\
\text { activities }\end{array}$ \\
\hline $\begin{array}{l}\text { Physical activity } \\
\text { knowledge }\end{array}$ & $\begin{array}{l}\text { Lesson in physical education } \\
\text { related to health benefits } \\
\text { of activity }\end{array}$ & $\begin{array}{l}\text { Explanation of health ben- } \\
\text { efits of resistance, force, or } \\
\text { flexibility exercises }\end{array}$ \\
\hline Fitness & $\begin{array}{l}\text { Activities whose objective is } \\
\text { to improve physical fitness }\end{array}$ & $\begin{array}{l}\text { Running, jumping rope, flex- } \\
\text { ibility activities }\end{array}$ \\
\hline Skill practice & $\begin{array}{l}\text { Activities whose objective is } \\
\text { to improve skills }\end{array}$ & $\begin{array}{l}\text { Repetition of ball throwing, } \\
\text { dribbling, shooting baskets }\end{array}$ \\
\hline Game play & $\begin{array}{l}\text { Games or rehearsals without } \\
\text { participation of teacher but } \\
\text { with rules set by teacher }\end{array}$ & $\begin{array}{l}\text { Dance rehearsal or sport's } \\
\text { game }\end{array}$ \\
\hline Free play & $\begin{array}{l}\text { Time to play without instruc- } \\
\text { tion or direction by teacher }\end{array}$ & $\begin{array}{l}\text { Free play where students } \\
\text { can choose to participate } \\
\text { or not }\end{array}$
\end{tabular}

SOFIT: System for observing fitness instruction time

* Adapted from McKenzie $\mathrm{TL}^{21}$

Qualitative observation: Observers made qualitative assessments in each school using a semi-structured guide. Observations began 30 minutes before classes started and ended when the school was empty of students. Observers registered everything about the school population and environment related to physical activity. Data analyses: Using the data from SOFIT, we calculated the percentage of time dedicated to each class context and each activity intensity. Percentage of time in MVPA was the sum of percentage of time walking and being "more active." ${ }^{24-26}$ We generated descriptive statistics stratified by observation period (recess or PE). Using univariate linear regression models, we tested whether percentage of class time in each context, grade in school, class duration, and hour of class initiation were significant predictors of percentage time in MVPA. We tested for effect modification by gender on the relationship between these predictor variables and percentage of time in MVPA. An effect modification was significant at an alpha $<0.10$. To test for significance, we calculated robust standard errors to account for the inter-conglomeration effect of school on activity. We performed all analyses using STATA 9.0 statistical software.
To analyze the qualitative data, we used the grounded theory approach, an inductive process where qualitative data are organized in different categories. ${ }^{27}$ We defined categories a priori as: 1) opportunities for physical activity, 2) barriers to physical activity, 3) sports equipment, and 4) facilities. We performed the qualitative analyses using FileMaker Pro 6.0.

\section{Results}

The qualitative observation detected that during the 4.5-hour school day there were two opportunities for physical activity: 1) recess and 2) PE. Recess occurred daily. Barriers to physical activity during recess included time dedicated to purchasing and consuming food, no organization of physical activities, no professor participation in student activity, and the prohibition of sports equipment such as balls, jump ropes, cones, and nets even though all schools had this equipment. Additionally, patios were overcrowded and observers noted that schools either had signs prohibiting running and playing during recess or that teachers enforced a no running and playing policy because of overcrowding.

The other opportunity for physical activity was PE. All 12 schools held PE once per week. Barriers to physical activity during PE included the frequent cancelling of PE in order to accommodate other activities, the sparse use of sports equipment and the lack of appropriate facilities. Facilities were limited to cement patios with uneven surfaces, holes, or other obstructions. Observers noted that during PE, generally one child would participate while the rest of the class observed and waited their turn.

There were a total of 431 SOFIT quantitative observations made during $26 \mathrm{PE}$ and 25 recess periods (table II). The average duration of recess was 29.6 \pm 2.1 minutes. The average duration of PE was $39.7 \pm 10.6$ minutes. During recess, students participated in MVPA 39.6 $24.5 \%$ of the time or $11.7 \pm 7.3$ minutes (figure 1). The majority of the MVPA during recess was walking $(89.4 \pm 20.2 \%)$. Students participated in MVPA $29.2 \pm 17.8 \%$ of PE or approximately $12.0 \pm 8.6$ minutes. Boys spent a greater percentage of time $(32.1 \pm 15.6 \%)$ in MVPA than girls $(25.7 \pm 15.6 \%)(\mathrm{p}<0.05)$. Students spent the majority of PE standing (figure 2).

The context of all recess periods was "free play." During PE the context was divided between six of the seven SOFIT categories (figure 3). The most common class contexts were "fitness" $(21.7 \pm 22.8 \%)$ and "skill practice" $(27.1 \pm 28.5 \%)$. Classes never participated in "fitness knowledge."

There was a significant effect modification by gen$\operatorname{der}(p<0.05)$ on the relationship between percentage of 
Table II

Select CHARACTERISTICS OF CLASSES AND STUdENTS OBSERVED USING SOFIT DIRECT OBSERVATION*

Classes (students)

\begin{tabular}{lll} 
Total number of observations & $5 \mathrm{I}$ & $(43 \mathrm{I})$ \\
\hline Observations during recess & $25 \quad(194)$ \\
\hline Observations during physical education class & $26 \quad(237)$ \\
\hline Boys & $52.1 \%$ \\
\hline 5th graders & $48.9 \%$
\end{tabular}

* Observations made in a sample of 12 public primary schools in Mexico City between November 2005 and March 2006

time in MVPA and class context. We stratified the data by gender and ran the univariate regression models for boys and girls separately (table III). For boys, the percentage of class time dedicated to "general knowledge" had a significant negative relationship ( $\beta=-0.47$, $p<0.01)$ and the percentage of time dedicated to "free play" had a significant positive relationship $(\beta=0.55$, $p$ $<0.01$ ) with percentage of time in MVPA. For girls, the percentage of class time dedicated to "fitness" had a negative relationship $(\beta=-0.15, p=0.07)$ and class duration had a positive relationship $(\beta=0.01, \mathrm{p}=0.06)$ with percentage of time in MVPA.

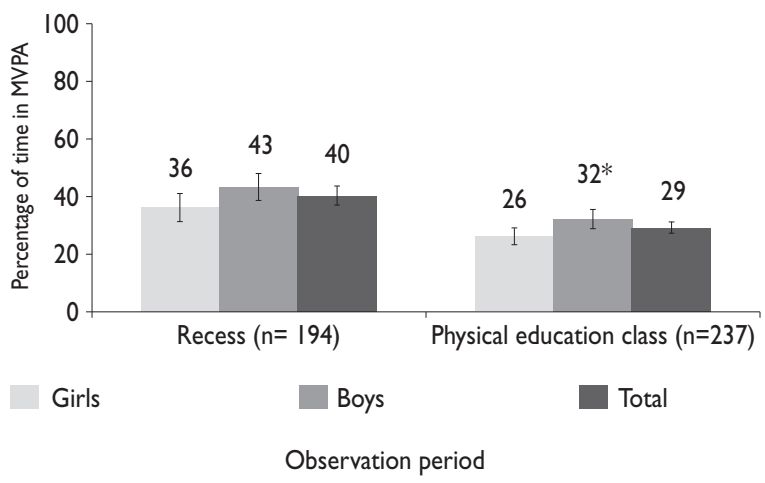

* Significantly different from girls, $p<0.05$

\# Measured through direct observation of students in a sample of 12 public primary school in Mexico City between November 2005 and March 2006

Figure I. Percentage of time in moderate-to-Vigorous PHYSICAL ACTIVITY (MVPA) BY OBSERVATION PERIOD ${ }^{\ddagger}$

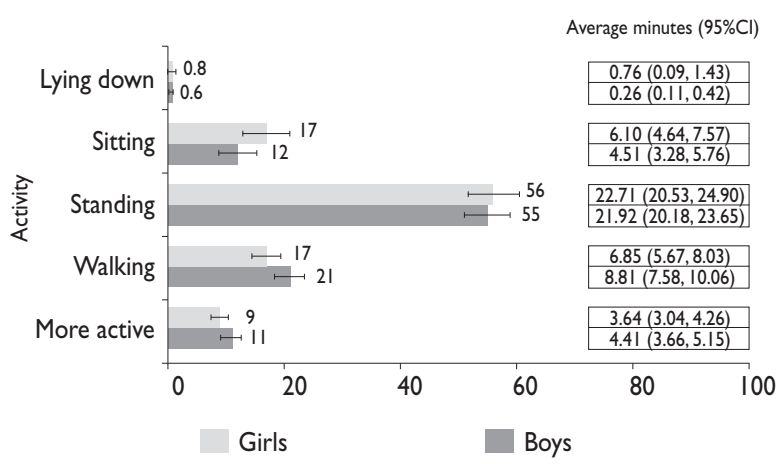

Percentage of the class time

* Measured through direct observation of students in a sample of 12 public primary school in Mexico City between November 2005 and March 2006

Figure 2. Percentage of time and time in MinUtes in each LEVEL OF PHYSICAL ACTIVITY INTENSITY DURING PHYSICAL EDUCATION CLASS (PE)*

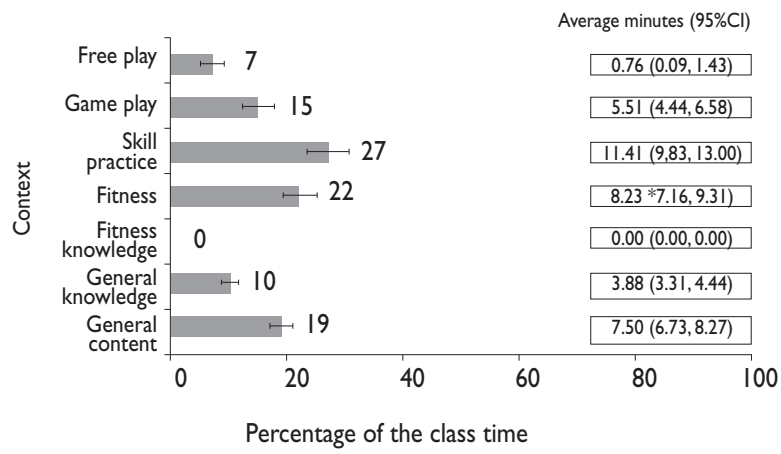

* Measured through direct observation of students in a sample of 12 public primary school in Mexico City between November 2005 and March 2006

Figure 3. Percentage of time and time IN MinUtes in each CLASS CONTEXT DURING PHYSICAL EDUCATION CLASS (PE)*

\section{Discussion}

In this sample of public primary schools in Mexico City, $4^{\text {th }}$ and $5^{\text {th }}$ grade students participated in little physical activity during the school day. Although the SEP policy states that students should participate in PE twice a week for 50 minutes per class, ${ }^{28} \mathrm{PE}$ only occurred once a week lasting, on average, less than 40 minutes. Additionally, the schools cancelled PE frequently because 
Table III

UNIVARIATE REGRESSION MODELS FOR INCREASED PERCENTAGE OF TIME IN MODERATE-TO-VIGOROUS PHYSICAL ACTIVITY (MVPA) DURING THE PHYSICAL EDUCATION CLASS (PE) IN BOYS AND GIRLS*

\begin{tabular}{|c|c|c|c|c|c|c|c|c|}
\hline \multirow[b]{2}{*}{ Predictor variable } & \multicolumn{4}{|c|}{ Boys } & \multicolumn{4}{|c|}{ Girls } \\
\hline & F-value & $\begin{array}{c}p \text {-value } \\
\text { of } F \text { statistics }\end{array}$ & $\begin{array}{l}\text { Coefficient } \\
(\text { SE })^{\ddagger}\end{array}$ & $\begin{array}{c}p \text {-value } \\
\text { of coefficient }\end{array}$ & F-value & $\begin{array}{c}p \text {-value } \\
\text { of } F \text { statistic }\end{array}$ & $\begin{array}{l}\text { Coefficient } \\
(\text { SE })^{\ddagger}\end{array}$ & $\begin{array}{c}p \text {-Value } \\
\text { of coefficient }\end{array}$ \\
\hline$\%$ of class general content & 0.96 & 0.35 & $0.13(0.14)$ & 0.35 & 0.78 & 0.40 & $0.09(0.10)$ & 0.40 \\
\hline$\%$ of class general knowledge & 24.19 & 0.00 & $-0.47(0.10)$ & 0.00 & 1.84 & 0.20 & $-0.14(0.11)$ & 0.20 \\
\hline$\%$ of class fitness & 0.33 & 0.58 & $-0.07(0.13)$ & 0.58 & 4.18 & 0.07 & $-0.15(0.08)$ & 0.07 \\
\hline$\%$ of class skill practice & 1.51 & 0.25 & $-0.11(-0.09)$ & 0.25 & 0.11 & 0.75 & $0.02(0.05)$ & 0.75 \\
\hline$\%$ of class game play & 0.21 & 0.66 & $-0.04(0.08)$ & 0.66 & 1.13 & 0.31 & $0.09(0.08)$ & 0.31 \\
\hline$\%$ of class free play & 21.60 & 0.00 & $0.55(0.12)$ & 0.00 & 1.54 & 0.24 & $0.11(0.09)$ & 0.24 \\
\hline Grade in school (4th or 5th) & 0.17 & 0.69 & $0.02(0.05)$ & 0.69 & 2.40 & 0.15 & $-0.07(0.04)$ & 0.15 \\
\hline Class duration (minutes) & 1.89 & 0.20 & $0.00(0.00)$ & 0.20 & 4.43 & 0.06 & $0.01(0.00)$ & 0.06 \\
\hline Hour of class initiation & 0.01 & 0.93 & $0.00(0.03)$ & 0.93 & 0.35 & 0.57 & $-0.01(0.02)$ & 0.57 \\
\hline
\end{tabular}

of professor absence or to accommodate other school events. United States' National Association for Sport and Physical Education (NASPE) recommends 150 minutes of PE per week..$^{29}$ The SEP policy does not reach this international recommendation and, thus, schools cannot offer students the internationally recommended time in PE. Ideally, the policy could be changed to increase class duration and frequency so that schools could dedicate more time to PE.

Students should spend $33-50 \%$ of PE in MVPA in order to reach the recommended 60 minutes of MVPA a day. ${ }^{30-33}$ Combining this recommendation with that of 150 minutes of PE per week generates a recommendation of 50-75 minutes of MVPA during PE per week. Our sample participated in MVPA approximately 12 minutes per week or 16-24\% of the recommendation. The students spent most of the class watching others and waiting their turn. In order to increase MVPAduring $\mathrm{PE}$, the class should aspire to all students participating at all times.

Activity guidelines for children emphasize offering a variety of activities which will hopefully lead to lifelong healthy activity. ${ }^{31} \mathrm{PE}$ offered a number of different activities. The most common class contexts were "fitness" and "skill practice," both of which involved the physical activity of students. However, greater than $20 \%$ of class time was dedicated to "general content" during which students are not intended to be active. ${ }^{21}$ Given the reduced time in PE per week, time in this context should be minimized. Gender modified the effect that context of the class had on percentage of time in MVPA. The MVPA of boys was associated with greater time in "free play." However, the class should not be entirely unstructured for two reasons: 1) girls would not reach MVPA recommendations and 2) the class would not fulfill the two important PE goals of enhancing physical, mental and emotional development, and developing an appreciation of physical activity's importance in health..$^{29,34}$ Gender differences should be recognized in order that both boys and girls increase activity during PE.

The context of "fitness knowledge" was not utilized by professors. One goal of a quality PE program is to teach students the value of an active lifestyle. ${ }^{29,35}$ Increasing time in "fitness knowledge" could facilitate reaching this goal. In addition, during recess there was no organization of physical activity; however, both boys and girls participated in more MVPA during recess than during PE, highlighting the need to increase activity during PE. Nonetheless, the majority of the activity during recess was walking around the school patio visiting food vendors. The overcrowding of the school patio, the policies against running, and the lack of equipment were barriers to participation in activity during recess. A number of international agencies recommend that schools provide students with at least one 20-minute discretionary recess period per day when students can participate in physical activity. ${ }^{36-39}$ Activity during recess can make a significant contribution to a student's total time in MVPA ${ }^{39}$ and, therefore, should be offered to students daily. 
This investigation was subject to a number of limitations. First, the intensity of the qualitative and quantitative methods used limited the number of schools we could observe. However, we selected typical schools and collected information until reaching information saturation and, therefore, our results should be generalizable to other schools in southern Mexico City with similar characteristics. ${ }^{19}$ Qualitative interviews with SEP administrators indicated that many of the opportunities and barriers for physical activity noted in this investigation were pervasive in the Mexico City school system. Second, the presence of observers in the schools may have affected the behaviour of students and/or PE teachers. This effect was likely very small, however, because study staff were in the schools every day for several months before conducting the observations. The students and teachers were accustomed to the staff presence and were likely not affected. Finally, this investigation only measured physical activity during specific time periods in school. We cannot speculate how other factors may influence the physical activity of students such as the physical activity in which the students participate outside of school or the home environment and parental attitudes toward physical activity.

In our sample of public primary schools in Mexico City, students are not reaching national or international recommendations regarding time in PE or time in MVPA during the school day. In order to increase the physical activity of students, schools should provide a daily period dedicated solely to physical activity and should increase the quantity and quality of PE. The school setting offers a great opportunity to influence the lives of students and to improve their health through physical activity during recess and PE. The public primary schools in Mexico City could take greater advantage of this opportunity in order to fight the emerging epidemic of unhealthy weight in Mexican children.

\section{Acknowledgements}

The original study was funded by the Healthy Lifestyles, Healthy People (HLHP) Project of the Pan American Health Organization (PAHO), the International Life Sciences Institute (ILSI) and the Centers for Disease Control and Prevention (CDC) of the United States. The opinions expressed herein are those of the authors and do not necessarily represent the views of PAHO, ILSI or CDC. Additional funds for different stages of the study were provided by two Mexican Institutions: the National Council for Science and Technology (CONACyT) and the Ministry of Health. The Principal Investigator was J. Rivera.
The authors would like to acknowledge the contribution of Deborah Salvo Dominguez and Eric A Monterrubio from the INSP, and Karen Kovacs, Guillermo Ayala Álvarez, and Elodia Silva of SEP, Mexico City.

\section{References}

I. Olaiz-Fernández G, Rivera-Dommarco J, Shamah-Levy T, Rojas R, Villalpando-Hernández $S$, Hernández-Avila $M$, et al. Encuesta nacional de salud y nutrición 2006 2nd ed. Cuernavaca, Mexico: INSP, 2006.

2. Cole TJ, Bellizzi MC, Flegal KM, Dietz WH. Establishing a standard definition for child overweight and obesity worldwide: international survey. BMJ 2000;320:1240-1243.

3. Rivera JA, Sepulveda-Amor J. Conclusions from the Mexican National Nutrition Survey 1999: translating results into nutrition policy. Salud Publica Mex 2003;45(suppl4):S565-S575.

4. Spielgelman BM, Flier JS. Obesity and the regulation of energy balance. Cell 200I; 104:53I-543.

5. Roberts $\mathrm{S}$. The role of physical activity in the prevention and treatment of childhood obesity. Pediatr Nurs 2000;26:33-37.

6. Laing EM, Massoni JA, Nickols-Richardson SM, Modlesky CM, O'Connor $\mathrm{PJ}$, Lewis RD.A prospective study of bone mass and body composition in female adolescent gymnasts. J Pediatr 2002;14I:21 I-216.

7. Schmitz KH, Jacobs DR, Hong CP, Steinberger J, Moran A, Sinaiko AR. Association of physical activity with insulin sensitivity in children. Int J Obes Relat Metab Disord 2002;26:1310-1316.

8. Haugland S, Wold B, Torsheim T. Relieving the pressure? The role of physical activity in the relationship between school-related stress and adolescent health complaints. Res Q Exerc Sport 2003;74:127-I 35. 9. Twisk JW, Kemper HC, van Mechelen W. Tracking of activity and fitness and the relationship with cardiovascular disease risk factors. Med Sci Sports Exerc 2000;32: 1455-I46I.

10. Trudeau F, Shephard RJ. Contribution of school programmes to physical activity levels and attitudes in children and adults. Sports Med 2005;35:89-105.

II.American Academy of Pediatrics Committee on Sports Medicine and Fitness and Committee on School Health. Physical fitness and activity in schools. Pediatrics 2000; 105: I 156-I I 57.

12. Simons-Morton BG, Taylor WC, Snider SA, Huang IW, Fulton JE. Observed levels of elementary and middle school children's physical activity during physical education classes. Prev Med 1994;23:437-44I. 13. McKenzie TL, Nader PR, Strikmiller PK, Yang M, Stone EJ, Perry CL, et al. School physical education: effect of the child and adolescent trial for cardiovascular health. Prev Med 1996;25:423-43I.

14. Heath EM, Coleman KJ. Evaluation of the institutionalization of the coordinated approach to child health (CATCH) in a US/Mexico border community. Health Educ Behav 2002;29:444-460.

15. Doak CM,Visscher TL, Renders CM, Seidell JC. The prevention of overweight and obesity in children and adolescents: a review of interventions and programmes. Obes Rev 2006;7: I I I-I36.

16. Flodmark CE, Marcus C, Britton M. Interventions to prevent obesity in children and adolescents: a systematic literature review. Int J Obes (Lond) 2006;30:579-589.

17. Kain J, Uauy R,Albala C,Vio F, Cerda R, Leyton B. School-based obesity prevention in Chilean primary school children: methodology and evaluation of a controlled study. Int J Obes Relat Metab Disord 2004;28:483-493.

18. Newes-Adeyi G, Helitzer DL, Caulfield LE, Bronner Y.Theory and practice: applying the ecological model to formative research for a WIC training program in New York State. Health Educ Res 2000; 15:283-29I. 
19. Pope C, Ziebland S, Mays N. Qualitative research in health care: Analyzing qualitative data. BMJ 2000;320:1 I4-I/6.

20. McKenzie TL, Sallis JF, Nader PR. SOFIT: System for observing fitness instruction time. Journal of Teaching in Physical Education 1991;1 I:195-205. 21. McKenzie TL. SOFIT: System for Observing Fitness Instruction Time Overview and Training Manual. San Diego CA: San Diego State University, 2002.

22. Rowe PJ, Schuldheisz JM, van der Mars H. Measuring physical activity in physical education: validation of the SOFIT direct observation instrument for use with first to eighth grade students. Pediatr Exerc Sci 1997;9:136-149. 23. Pope RP, Coleman KJ, Gonzalez BF, Heath EM.Validating SOFIT during physical education in a predominantly Hispanic community. Med Sci Sports Exerc 2000;Supp32(5): 328.

24. U.S. Department of Health and Human Services. Physical activity and health: a report from the Surgeon General. Atlanta, GA: US Department of Health and Human Services, Centers for Disease Control and Prevention, National Center for Chronic Disease Prevention and Health Promotion, 1996.

25. Ainsworth BE, Haskell WL, Whitt MC, Irwin ML, Swartz AM, Strath SJ, et al. Compendium of physical activities: an update of activity codes and MET intensities. Med Sci Sports Exerc 2000;Supp 32(9):498-516.

26. Caspersen CJ, Powel KEl, Christensen GM. Physical activity, exercise, and physical fitness: definitions and distinctions for health-related research. Public Health Rep 1985;100:126-130.

27. Glaser B, Strauss A. The discovery of grounded theory: strategies for qualitative research. Ist ed. London, England:Weidenfeld and Nicolson, 1968. 28. Administración Federal de Servicios Educativos en el Distrito Federal Dirección General de Educación Física. Dirección General de Planeación, Programación y Evaluación Educativa: Lineamientos para la Organización y Funcionamiento de los Servicios de Educación Física en el Distrito Federal 2006-2007. Mexico City: 2006.

29. National Association for Sport and Physical Education. Moving into the future: national standards for physical education. 2nd ed. Reston VA: National Association for Sport and Physical Education. 2004.

30. Institute of Medicine. Dietary reference intakes for energy, carbohydrate, fiber, fat, fatty acids, cholesterol, protein, and amino acids. Washington DC: National Academics Press, 2002.
31. National Association for Sport and Physical Education. Physical activity for children: a statement of guidelines, 2nd ed. Reston,VA: National Association for Sport and Physical Education. 2004.

32. United States Department of Health and Human Services \& United States Department of Agriculture. The dietary guidelines for Americans, 2005 6th ed.Washington DC: United States Department of Health and Human Services \& United States Department of Agriculture. 2005. 33. Scruggs PW, Beveridge SK, Eisenman PA, Watson DL, Shultz BB, Ransdell LB. Quantifying physical activity via pedometry in elementary physical education. Med Sci Sports Exerc 2003;35: 1065-107I.

34. Dirección General de Educación Física. Subsecretaría de Educación Básica. Secretaria de Educación Pública. Programa de Educación Física. Ist ed. ISBN 968-29-6344-3:1994.

35. Council of Physical Education for Children. Physical education is critical to a complete education: a position paper from the National Association for Sport and Physical Education. Reston,VA: Council of Physical Education for Children. 2002.

36. Centres for Disease Control and Prevention. Guidelines for school and community programs to promote lifelong physical activity among young people. MMWR 1997;46:12.

37. United States Department of Health and Human Resources \& United States Department of Education. Promoting better health for young people through physical activity and sport. Washington DC: United States Department of Health and Human Resources \& United States Department of Education. 2000.

38. National Association for the Education of Young Children:The value of school recess and outdoor play. [Consulted Feb 20, 2007]. Available at: http: //www.naeyc.org/ece/ I998/08.asp

39. Council of Physical Education for Children. Recess for elementary school students: a position paper from the National Association for Sport and Physical Education. Reston,VA: Council of Physical Education for Children. 2006. 